\title{
Prevalence, Symptomology, Detection and Molecular Characterization of Citrus Viroid V Infecting New Citrus Cultivars in Pakistan.
}

\section{Amjad Ali}

Bahauddin Zakariya University

Ummad U. Umar ( $\boldsymbol{Q}$ ummad.umar@bzu.edu.pk)

Bahauddin Zakariya University https://orcid.org/0000-0002-2582-9603

\section{Sohail Akthar}

University of Agriculture Faisalabad

\section{Ateeq U. Rehman}

Bahauddin Zakariya University

\section{Muhammad Taimoor Shakeel}

The Islamia University of Bahawalpur Pakistan

\section{Muhammad Nouman Tahir}

Bahauddin Zakariya University

\section{Sagheer Atta}

Ghazi University

\section{Fatih Ölmez}

Sivas Bilim ve Teknoloji Universitesi

\section{Rashida Parveen}

Bahauddin Zakariya University

\section{Research Article}

Keywords: Citrus Viroids, Pospiviroidae, Etrog citron, Biological indexing, RT-PCR.

Posted Date: February 9th, 2022

DOI: https://doi.org/10.21203/rs.3.rs-1310164/v1

License: (c) (i) This work is licensed under a Creative Commons Attribution 4.0 International License. Read Full License 


\section{Abstract}

\section{Background}

Citrus plants are prone to infection by different viroids which deteriorate their vigor and production. Citrus viroid V (CVd-V) is among the six citrus viroids, belongs to genus Apscaviroid (family Pospiviroidae) which induces symptoms of mild necrotic lesions and cracks.

\section{Methods and Results}

A survey was conducted to evaluate the prevalence of $\mathrm{CVd}-\mathrm{V}$ in core and non-core citrus cultivated areas of Punjab, Pakistan. A total of 154 samples from different citrus cultivars were tested for CVd-V infection by RT-PCR. The results revealed $66.66 \%$ disease incidence of CVd-V. Citrus cultivars Palastinia Sweet lime, Roy Ruby, Olenda Valencia, Kaghzi lime, and Dancy were identified as new citrus hosts of CVd-V for the first time from Pakistan. The viroid infection was confirmed by biological indexing on indicator host Etrog citron. The reported primers used for the detection of CVd-V did not amplified, rather showed non-specific amplification, which led to the designing of new primers. Sequencing analysis confirmed the new host of CVd-V showing 98 - 100\% nucleotide sequence homology with those reported previously from other countries while $100 \%$ sequence homology to the isolates reported from Pakistan. Based on phylogenetic analysis using all CVd-V sequences in GenBank, two main CVd-V groups (I and II) were identified, and newly identified sequences during this study fall in the group I. All isolates of Pakistan showed high sequence homology with other isolates of CVd-V from Iran and USA whereas; the isolates from China, Japan, Tunisia, and Africa are distantly related. It is evident that CVd-V is spreading in all citrus cultivars.

\section{Conclusion}

The study revealed that there are some changes in the nucleotide sequences $\mathrm{CVd}-\mathrm{V}$ which made difficult for their detection using reported primers. Whereas, new back-to-back designed primers (CVd-V AF1/CVdV AR1) detected CVd-V successfully and obtained an expected amplified product of CVd-V with 294bp. Palastinia Sweet lime, Roy Ruby, Olenda Valencia, Kaghzi lime, and Dancy were identified as new citrus hosts of CVd-V for the first time from Pakistan with these newly designed primers.

\section{Introduction}

Viroids are the smallest, low molecular weight, infectious obligate endo-parasites having circular, singlestranded RNAs. Viroids have no protein coat, they multiply and replicate through RNA in the host plant and cause-specific diseases in plants, that's why known as an important viral like phytopathogenic agent $[1,2,3,4]$.All reported viroids from different host plants are divided into two different families named Pospiviroidae (having specific central conserved region and replicate in the nucleus) and Avsunviroidae (having no specific central conserved region and replicate in the chloroplast) $[5,6,7]$. 
Citrus plants are infected by different seven viroid species belong to the family Pospiviroidae and divided into different distinct genera based on their biological and physiological properties, such as Citrus exocortis viroid (CEVd, Pospiviroid), Citrus hop stunt viroid (CHSVd, Hostuviroid) [8], Citrus bark cracking viroid (CBCVd, Cocadviroid), Citrus bent leaf viroid (CBLVd, Apscaviroid), Citrus viroid III (CVd-III, Apscaviroid), Citrus viroid V (CVd-V, Apscaviroid) and Citrus viroid VI (CVd-Vl, Apscaviroid) $[9,10,11]$. Potato spindle tuber viroid (PSTVd) was the first known viroid which belongs to the family Pospiviroidae. The likely secondary structure of the member of Pospiviroidae consists of five structural domains, the right terminal, central conserved, pathogenicity, variable, and left-terminal domain [12]. CVd-V belongs to the genus Apscaviroid of family Pospiviroidae [13, 14, 15]. The species of Apscaviroid do not produce well-defined disease but the effect was observed on the plant in the form of stunting and yield reduction $[16,17]$. Genomic study of CVd-V indicates 293-294 nucleotides bases, higher GC contents, with strong TCR (Terminal Conserved Regions) and characterized by a rod-like conformation with $68.7 \%$ paired nucleotides. CVd-V has a single unique character as compared to a member of the genus Apscaviroid with a lower Central Conserved Region (CCR) and strand of CVd-V have C197-U transition that changes the C-G base pair with G-U base pair [18].

Recently, CVd-V was reported in citrus cultivars from Pakistan by Cao et al. [18] with 294 genomic nucleotides. It was also reported from Japan due to its unusual ability to replicate in Atalantia citroides (a citrus relative resistant to or unaffected by all previously known citrus viroids including CVd-I, CEVd, CVdIV, CVd-II, and CVd-III [19]. It induces the symptoms of mild necrotic lesions and fissure (cracks), occasionally chockfull with gum in the stems of indicator plants Etrog citron (Citrus medica L.). Inoculated indicator plants were-placed in controlled conditions where the temperature range was 28$32^{\circ} \mathrm{C}$, and showed symptoms of bark scaling, cracking of stems, leaf curling, and lesions on the mid-vein of a leaf [20]. Synergistic effect of CVd-V with other viroids in mixed infection on indicator plant (Etrog citron) pronounced the leaf symptoms and dwarfing $[21,22]$. Synergistic effect of CVd-V with CBLVd and CVd-III on Etrog citron showed severe epinasty and stunting with multiple lesions in the mid vein of the plant [23]. Although CVd-V was reported in citrus cultivars from different regions of the world, however, recently it was reported from Turkey, Nepal, Pakistan [18, 24], California [25], and Australia [15].

Recent spread of CVd-V in different parts of the world raised interest in conducting a study that may cover the geographic distribution of CVd-V in Pakistan, particularly, in Punjab, the most contributing province in citrus production. It is also pertinent to mention here that now it has been proved that citrus viroids are among the major problems for the citrus industry hampering per acre yield $[26,27,28]$. To evaluate the existence and dissemination of $\mathrm{CVd}-\mathrm{V}$ in core and non-core citrus cultivated areas of Punjab, a survey was conducted to identify the new citrus hosts of CVd-V using RT-PCR with reported and newly designed primers.

\section{Methods}

\subsection{Survey of citrus orchards and samples collection}


A survey was conducted from April 2018 to May 2019 for the collection of viroid-infected samples from citrus cultivated areas of Punjab, Pakistan. A total of 154 samples were collected from seven Districts (Sahiwal, Sargodha, Khanewal, Rahim Yar Khan, Multan, Layyah, Toba Tek Singh) of Punjab, Pakistan. Samples were collected from 8-25 years old citrus cultivars, i.e., 12 from 'Feutrell's Early', 53 from 'Kinnow' mandarin (Citrus reticulata), 32 from sweet orange (C. sinensis), 21 from sweet lime (C. limettioides), 21 from grapefruits (C. paradisi), 04 from lemon (C. jambhiri), 08 from tangerines (C. tangerina) and 03 from tangelos (C. tangelo). All collected samples were showing characteristic symptoms including bark cracking, mild leaf bending, lesions on the mid-vein of leaf, and severe stunting.

\subsection{Biological indexing}

Biological indexing was done by collecting $\mathrm{CVd}-\mathrm{V}$ infected bud woods from three infected citrus cultivars of sweet orange, sweet lime, and Kinnow, and stored in a refrigerator. One percent solution of sodium hypochlorite was used to disinfect the buds and other grafting related helping material (scissor, forceps, and surgical blades). Each pot contained one indicator Arizona 861-S1 Etrog citrons plant. The T-grafting method was performed to fix the infected CVd-V buds on an indicator plant Arizona 861-S1 Etrog citrons on rough lemon rootstock $[29,30]$. The indicator plants were cut $30 \mathrm{~cm}$ above from the soil surface; bud was adjusted into the cut and wrapped carefully for two weeks. Grafted plants were maintained at hot temperature in the greenhouse at 32 to $40^{\circ} \mathrm{C}$ in day and 24 to $32^{\circ} \mathrm{C}$ at night. The symptoms of $\mathrm{CVd}-\mathrm{V}$ were observed two to three months after grafting.

\subsection{Total RNA extraction and RT-PCR assays}

$100 \mathrm{mg}$ of citrus plant leaf/ bark sample was expunged in the centrifuge tube and grounded with plastic micropestle with the help of liquid nitrogen. 500 $\mu$ l of Plant Triazol RNA Regent (Invitrogen inc. USA) was added into crushed sample and mixed well. The sample tubes were incubated at room temperature for few minutes. Tubes were centrifuged for 2 minutes at 12000rpm after incubation and supernatant was transferred carefully to the new $1.5 \mathrm{ml}$ tube. $100 \mu \mathrm{l}$ of $5 \mathrm{M} \mathrm{NaCl}$ and $300 \mu \mathrm{l}$ of chloroform were added in the supernatant, mixed thoroughly and centrifuged at $12000 \mathrm{rpm}$. The top separated phase was transferred to new $1.5 \mathrm{ml}$ tube. 2-propanol was added in an equal volume and incubated for 10-15 minutes at room temperature to precipitate RNA. After incubation, the tubes were centrifuged at maximum speed for one minute and pellet of RNA was suspended and dried. Nuclease free water was added to dissolve the pellet and stored at $-20^{\circ} \mathrm{C}$. DNase treatment was given to extracted RNA samples. The RNA concentration and purity was checked by Nano-drop.

\section{4 cDNA synthesis}

cDNA was synthesized by RevertAid ${ }^{\text {TM }}$ First-Strand cDNA kit (Applied Bio-system, USA) using the protocol of Fiore et al. [31]. A reaction mixture of each sample contained $5 \mu \mathrm{l}$ of RNA, $1 \mu \mathrm{l} 10 \mathrm{mM}$ dNTPs, $1 \mu \mathrm{l}$ random DNA hexanucleotides, and $3 \mu$ nuclease-free water was prepared. The reaction profile included denaturation at $65^{\circ} \mathrm{C}$ for 5 minutes, reverse transcription with M-MLVRT at $42^{\circ} \mathrm{C}$ for 60 minutes, and the terminal temperature of $85^{\circ} \mathrm{C}$ for 10 minutes. 


\subsection{Primer designing}

Specific primers of viroids were-designed using the software Mega X. The primers were designed to test Citrus viroid $V$ having complete sequences with Accession Numbers retrieved from NCBI. Designed primers were analyzed by BLAST search to confirm the specificity for detection. Newly designed back to back specific primers were CVd-V AF1 (AGGAGWAGAAAGTACTCACCTG) and CVd-V AR1 (CTWCTCCTCTGCTTTTATT) with the amplicon product size of $294 \mathrm{bp}$.

\subsection{RT-PCR optimization with newly designed primers}

After RT reaction, PCR amplification of CVd-V was done by using $1 \mu \mathrm{l}$ of cDNA as a template with mixture containing $1 \mu \mathrm{l}$ of each target specific reported primers $(10 \mathrm{mM}) \mathrm{CVd}-\mathrm{V}$ by Cao et al. (2013), $0.5 \mu \mathrm{l}$ of $10 \mathrm{mM}$ dNTPs, $1.7 \mu \mathrm{l}$ of $25 \mathrm{mM} \mathrm{MgCl} 2,0.3 \mu \mathrm{l}$ of Taq DNA polymerase (Invitrogen), $2.5 \mu \mathrm{l}$ of $10 \mathrm{X}$ buffer and remaining deionized sterile water to make $25 \mu \mathrm{l}$ of total reaction volume. Conditions for the amplification of CVd-V were; initial denaturation at $95^{\circ} \mathrm{C}$ for 5 minutes, followed by 35 cycles of $95^{\circ} \mathrm{C}$ for 30 seconds, $57{ }^{\circ} \mathrm{C}$ for 30 seconds and $72{ }^{\circ} \mathrm{C}$ for 45 seconds and a final extension at $72^{\circ} \mathrm{C}$ for 10 minutes. The amplified product was confirmed by gel electrophoresis in $1.5 \%$ agarose with the expected $294 \mathrm{bp}$ band size of CVdV.

Table 1

Primers of CVd-V used during the study

\begin{tabular}{|lllll|}
\hline Viroid & Primer Name & Sequences 5囚-3囚 & Size & References \\
\hline CVd-V & CVd-VF & gacgaaggccggtgagcagtaagcc & 294 bp & Cao et al. [18] \\
& CVd-VR & gacgacgacaggtgagtactttc & & \\
CVd-V & CVd-V AF1 & aggagwagaaagtactcacctg & $294 \mathrm{bp}$ & This study \\
& CVd-V AR1 & ctwctcctctgcttttatt & & \\
\hline
\end{tabular}

\subsection{Purification of PCR products, Sequencing, and phylogenetic analyses}

Purification of PCR products was performed by FavorPrep PCR Clean-up mini-kit (Favorgen Bioteck Corp; cat. no: FAPCK001-1). Purified PCR products were sequenced using sanger sequencing technology. The sequences were aligned with Mega X software and compared with other isolates of GenBank using online BLAST on NCBI [32]. After cleaning, the sequences were submitted to database, and accession numbers were obtained. Configuration was done using MUSCLE expertise and maximum probability phylogenetic trees of citrus viroid were constructed using Mega X software version 10.1.8 [33]. The evolutionary distances were computed using the Maximum Composite Likelihood method [34] and are in the units of the number of base substitutions per site, and hence the percent nucleotide sequence identity was calculated. For the construction of the phylogenetic tree of $\mathrm{CVd}-\mathrm{V}$, seventeen other $\mathrm{CVd}-\mathrm{V}$ sequences were 
obtained from GenBank. Apple scar skin viroid ASSVd; DQ362906) was used as outgroup in the analysis. All isolates of citrus viroid were reported with their accession number, country name, and citrus cultivar. Percentage identities with other viroids were also noted.

\section{Results}

\subsection{Symptoms of observation}

During the survey, many characteristic symptoms of viroids including bark cracking, browning of leaf tips, petioles necrosis, mild leaf bending, lesions on the mid-vein of leaves, and severe stunting were observed on all samples of citrus from several locations (Multan, Sahiwal Citrus germplasm, Sargodha, Toba Tek Singh, Layyah, Rahim Yar Khan, and Khanewal) of Punjab, Pakistan. It was observed during field surveys that Kinnow mandarin plants were showing severe bark scaling as compared to other citrus cultivars, while others were showing yellowing, severe stunting, gumming, and leaf curling.

\subsection{Molecular Detection of Citrus Viroid V (CVd-V) through RT-PCR}

For the detection of CVD-V, reported primers were used [18]. However, those primers were unable to produce specific PCR products. Therefore, newly designed specific viroid primers by MEGA X were used for the detection. Newly designed primers detected CVd-V successfully with the amplification product of 294 bp (Fig. 1). CVd-V was detected in 102 out of 154 samples through RT-PCR, with $66.66 \%$ disease incidence. Cultivar-wise disease incidence of $\mathrm{CVd}-\mathrm{V}$ was also calculated from all collected samples. Maximum disease incidence was observed on grapefruit (85.71\%) as compared to other cultivars, tangerine (75\%), Feutrell's Early "mandarin" (75\%), sweet lime (71.42\%), tangelos (66.66\%), Kinnow mandarin (62.26\%), sweet orange (53.12\%), and lemon (50\%) (Table 2). Palestine Sweet lime (C. limettioides), Roy Ruby (Citrus paradisi), Olenda Valencia (C. sinensis), Kaghzi lime (C. aurantifolia) and Dancy ( $C$. reticulata) identified as new citrus host plants of $C V d-V$ for the first time from Pakistan, detected by newly designed primers. Furthermore, the co-infection of $\mathrm{CVd}-\mathrm{V}$ was also established with other viroids in most tested samples. 
Table 2

Percent Incidence of CVd-V in citrus cultivars tested by RT-PCR.

\begin{tabular}{|c|c|c|c|c|c|c|}
\hline $\begin{array}{l}\text { Sr. } \\
\text { No. }\end{array}$ & Cultivars & Collection Districts & $\begin{array}{l}\text { Total no. } \\
\text { of } \\
\text { samples }\end{array}$ & $\begin{array}{l}\text { Tested } \\
\text { for CVd- } \\
\text { V }\end{array}$ & Positive & $\begin{array}{l}{ }^{*} \mathrm{D} . \mathrm{I} \\
\text { of } \\
\text { CVd- } \\
\text { V (\%) }\end{array}$ \\
\hline 1 & $\begin{array}{l}\text { Kinnow } \\
\text { Mandarin }\end{array}$ & $\begin{array}{l}\text { Layyah, Toba Tek Singh, Rahim } \\
\text { Yar Khan, Multan, Khanewal }\end{array}$ & 53 & 53 & 33 & 62.26 \\
\hline 2 & $\begin{array}{l}\text { Feutrell Early } \\
\text { 'mandarin' }\end{array}$ & $\begin{array}{l}\text { Layyah, Rahim Yar Khan, } \\
\text { Multan }\end{array}$ & 12 & 12 & 9 & 75 \\
\hline 3 & $\begin{array}{l}\text { Sweet } \\
\text { Orange }\end{array}$ & $\begin{array}{l}\text { Rahim Yar Khan, Multan, } \\
\text { Khanewal, Sargodha, Sahiwal }\end{array}$ & 32 & 32 & 17 & 53.12 \\
\hline 4 & Grapefruit & $\begin{array}{l}\text { Rahim Yar Khan, Multan, } \\
\text { Khanewal, Sargodha, Sahiwal }\end{array}$ & 21 & 21 & 18 & 85.71 \\
\hline 5 & Sweet Lime & $\begin{array}{l}\text { Khanewal, Layyah, Sargodha, } \\
\text { Sahiwal }\end{array}$ & 21 & 21 & 15 & 71.42 \\
\hline 6 & Lemon & Sargodha, Khanewal, Sahiwal & 4 & 4 & 2 & 50 \\
\hline 7 & Tangerines & Sargodha, Sahiwal & 8 & 8 & 6 & 75 \\
\hline 8 & Tangelos & Sargodha, Sahiwal & 3 & 3 & 2 & 66.66 \\
\hline
\end{tabular}

All grafted citron plants produced moderate to severe symptoms of viroids infection (Fig. 2). Moderate symptoms related to CVd-V (leaf curling, bark scaling, necrosis of mid-veins) initiated in 6 to 8 weeks. Severe stunting by viroids infection on citrons plants were produced with an infected scion of Dancy 'sweet orange'. Additionally, inoculated with viroid-infected scion, citrons plants were examined by RTPCR. RT-PCR results revealed that CVd-V with 294bp band size is present in citron plants. 
Table 3

Results of biological indexing and RT-PCR analyses for detection of CVd-V

\begin{tabular}{|c|c|c|c|c|}
\hline $\begin{array}{l}\text { Isolate } \\
\text { ID }\end{array}$ & District & Cultivar name & Symptoms on Citron & $\begin{array}{l}\text { Detection of CVd-V through } \\
\text { RT-PCR }\end{array}$ \\
\hline P-236 & Sahiwal & $\begin{array}{l}\text { Palastina Sweet } \\
\text { Lime }\end{array}$ & $\begin{array}{l}\text { Bark shelling, leaf } \\
\text { curling }\end{array}$ & + \\
\hline $\begin{array}{l}\mathrm{Kw}- \\
159\end{array}$ & $\begin{array}{l}\text { Rahim Yar } \\
\text { Khan }\end{array}$ & Kinnow & Moderate symptoms & + \\
\hline $0-250$ & Sahiwal & Valencia orange & $\begin{array}{l}\text { Moderate leaf } \\
\text { curling, }\end{array}$ & + \\
\hline R. 213 & Sargodha & Roy Ruby & $\begin{array}{l}\text { Bark shelling, leaf } \\
\text { curling }\end{array}$ & + \\
\hline $\begin{array}{l}\text { Kw- } \\
160\end{array}$ & $\begin{array}{l}\text { Rahim Yar } \\
\text { Khan }\end{array}$ & Kinnow & $\begin{array}{l}\text { Moderate leaf } \\
\text { curling, }\end{array}$ & + \\
\hline D-202 & Sargodha & Dancy & Severe bark cracking & + \\
\hline
\end{tabular}

Disease incidence of district-wise collected samples was also calculated after testing through RT-PCR and the expected band of CVd-V with 294 bp was amplified on (65.38\%) from Multan, (58.06\%) from Khanewal, (77.77\%) from Sahiwal, and (66.66\%) from Toba Tek Singh. Moreover, (68.42\%) from Layyah, (61.9\%) from Rahim Yar Khan and (66.66\%) from Sargodha showed positive results for CVd-V. Maximum disease incidence was found to be in core citrus-growing areas (Sargodha, Sahiwal, and Toba Tek Singh) of Punjab, Pakistan.

Table 4

District-wise disease incidence (\%) of CVd-V

\begin{tabular}{|lllll|}
\hline Location & Tested samples & Positive for CVd-V & Incidence (\%) & *Field symptoms \\
\hline Multan & 26 & 17 & 65.38 & BC and St. \\
\hline Khanewal & 31 & 18 & 58.06 & St. and DB \\
\hline Sahiwal & 27 & 21 & 77.77 & BC, LC \\
\hline Toba Tek Singh & 12 & 8 & 66.66 & BC and St. \\
\hline Layyah & 19 & 13 & 68.42 & DB and St. \\
\hline Sargodha & 18 & 12 & 66.66 & BC and DB \\
\hline Rahim Yar Khan & 21 & 13 & 61.9 & BC \\
\hline Total & 154 & 102 & 66.66 & \\
\hline * BC: Bark Cracking, St: Stunting, DB: Dieback, LC: leaf curling & \\
\hline
\end{tabular}


The obtained sequences of $\mathrm{CVd}-\mathrm{V}$ with their accession numbers are given in Table 5. All five isolates have shared a high genomic nucleotide identity ranging from $98-100 \%$. 
Table 5

List of isolates with geographic location characterized during this study.

\begin{tabular}{|c|c|c|c|c|c|c|}
\hline $\begin{array}{l}\text { Sr. } \\
\text { No. }\end{array}$ & Viroid & Location/District & Host & $\begin{array}{l}\text { Accession } \\
\text { No. }\end{array}$ & Reference & Country \\
\hline 1 & $\begin{array}{l}\text { CVd- } \\
\mathrm{V}\end{array}$ & Sahiwal & $\begin{array}{l}\text { Palastina sweet } \\
\text { lime }\end{array}$ & MN885660 & This study & Pakistan \\
\hline 2 & $\begin{array}{l}\text { CVd- } \\
\text { V }\end{array}$ & Sargodha & Roy Ruby & MN885656 & This study & Pakistan \\
\hline 3 & $\begin{array}{l}\text { CVd- } \\
\text { V }\end{array}$ & Sahiwal & Kaghzi lime & MN885558 & This study & Pakistan \\
\hline 4 & $\begin{array}{l}\text { CVd- } \\
\mathrm{V}\end{array}$ & Sahiwal & Olenda Valencia & MN885657 & This study & Pakistan \\
\hline 5 & $\begin{array}{l}\text { CVd- } \\
\text { V }\end{array}$ & Sargodha & Dancy & MN885659 & This study & Pakistan \\
\hline 6 & $\begin{array}{l}\text { CVd- } \\
\text { V }\end{array}$ & - & Atlantia citroides & EF617306 & Serra et al. [10] & Spain \\
\hline 7 & $\begin{array}{l}\text { CVd- } \\
\text { V }\end{array}$ & California & madurensis Lour & MF477876 & Dang et al. [25] & USA \\
\hline 8 & $\begin{array}{l}\text { CVd- } \\
\text { V }\end{array}$ & El Manar & Citrus sinensis & KC460711 & $\begin{array}{l}\text { Elleuch et al. } \\
\text { [11] }\end{array}$ & Tunisia \\
\hline 9 & $\begin{array}{l}\text { CVd- } \\
\text { V }\end{array}$ & Punjab & Kinnow & JQ348924 & Cao et al. [18] & Pakistan \\
\hline 10 & $\begin{array}{l}\text { CVd- } \\
\text { V }\end{array}$ & Azadi, Mashhad & $\begin{array}{l}\text { Solanum } \\
\text { lycopersicum }\end{array}$ & KY654684 & $\begin{array}{l}\text { Ebrahimi et al. } \\
\text { [2] }\end{array}$ & Iran \\
\hline 11 & $\begin{array}{l}\text { CVd- } \\
\text { V }\end{array}$ & - & Grapefruit & GQ466068 & $\begin{array}{l}\text { Hashemian et } \\
\text { al. [22] }\end{array}$ & Spain \\
\hline 12 & $\begin{array}{l}\text { CVd- } \\
\text { V }\end{array}$ & Punjab & Saccari & JQ348928 & Cao et al. [18] & Pakistan \\
\hline 13 & $\begin{array}{l}\text { CVd- } \\
\text { V }\end{array}$ & & Seminole tangelo & EU433392 & Serra et al. [10] & Spain \\
\hline 14 & $\begin{array}{l}\text { CVd- } \\
\mathrm{V}\end{array}$ & CRI, Nelspruit & Etrog medica & KY110720 & Steyn et al. [30] & $\begin{array}{l}\text { South } \\
\text { Africa }\end{array}$ \\
\hline 15 & $\begin{array}{l}\text { CVd- } \\
\text { V }\end{array}$ & Tunis & Citrus limon & JQ072089 & Hamdi et al. [8] & Tunisia \\
\hline 16 & $\begin{array}{l}\text { CVd- } \\
\text { V }\end{array}$ & Tunis & Citrus sinensis & KC460712 & $\begin{array}{l}\text { Elleuch et al. } \\
\text { [11] }\end{array}$ & $\begin{array}{l}\text { North } \\
\text { Africa }\end{array}$ \\
\hline 17 & $\begin{array}{l}\text { CVd- } \\
\text { V }\end{array}$ & Tunis & Citrus sinensis & KC460712 & $\begin{array}{l}\text { Elleuch et al. } \\
\text { [11] }\end{array}$ & $\begin{array}{l}\text { North } \\
\text { Africa }\end{array}$ \\
\hline
\end{tabular}


The sequence of isolates of CVd-V characterized here were analyzed along with sequences of other isolates available in database. The phylogenetic tree was constructed keeping 1000 bootstrap value. The phylogenetic tree divided into two main groups. Group one contains all sequencing obtained during this study and with a sequences of Japan, Spain, South Africa, USA, Iran, Pakistan, China, Tunisia and North Africa. Group two contain only one sequence (JQ348931) which was previously reported from Pakistan. The Neighbor-Joining tree depicted that the four out of five isolates of CVd-V characterized here are grouped with the Iran isolate (GQ466068), while the isolate R-214 (MN885656) segregates with Spain isolate EF617306 (Fig. 4). The sequence identity of these seven isolates including five of the current study ranges from 98 to $100 \%$ (Supplementary Table). Other closely related isolates include the isolates from Pakistan (JQ348930), from the USA (MF477859, MF477876), and Iran (KY654684). The isolates from China, Japan, Tunisia, and Africa are distantly related in the tree showing comparatively less identity with our isolates. Roy Ruby isolate (R-214; MN885656) showed $100 \%$ homology with the isolate of Spain (EF617306). The isolate from Olenda Valencia (0-250; MN885657) was also $100 \%$ identical to Irani isolate (GQ466068). All isolates of Pakistan showed a high sequence homology during blasting on NCBI with the other isolates of CVd-V submitted from others countries (Fig. 4).

\section{Discussion}

Pakistan is a citrus-growing country where 0.198 million hectares area is under citrus fruits cultivation that is higher than other horticultural fruit crops grown in the country [26]. Being an important export crop of Pakistan, Punjab produces more than $97 \%$ citrus as compared to other provinces. The cultivated area of citrus in Punjab is 183,210 hectares due to adequate water, and favorable environmental conditions for the citrus growth [35]. Citrus viroids are becoming a threat to the citrus production of Pakistan. Viroid species such as CEVd, CVd-II, CVD-I, CVd-III, CVd-IV, and CVd-V have been identified from citrus cultivars of Pakistan [18]. In this study, we identified some new citrus hosts of CVd-V from Pakistan. Previously reported primers were unable for specific amplification of viroids [18]. This is because one of the primer pair (reverse primer) was unable to anneal with CVd-V, rather showing homology with other viroids upon BLAST analysis. This was further confirmed by sequence alignment of the CVd-V available in database, in which one primer pair was not found in all viroids. (Supplementary Fig.) Thus, new back-to-back primers (CVd-V AF1/CVd-V AR1) were designed and used for detection which obtained an expected amplified product of CVd-V with 294bp. Palastinia Sweet lime, Roy Ruby, Olenda Valencia, Kaghzi lime, and Dancy were identified as new citrus hosts of CVd-V for the first time from Pakistan with these newly designed primers. Whereas, Cao et al. [18] reported CVd-V from Kinnow and Feutrell's Early, Mosambi and Saccari, sweet oranges, grapefruits, sweet limes, acid limes, sour orange, lemon, and Jatti Khatti for the first time from Pakistan. However, earlier Cao et al. [36] described most citrus cultivars in Pakistan as the host of two or three viroid species. CVd-V produces mixed infection with other viroids and indicator plants showed leaf curling on co-infection with CBLVd $[10,37]$. New host Atalantia citroides a citrus host of CVd$\checkmark$ was also identified from Japan by Ito et al. [38] and, only this viroid can replicate in A. citroides [10]. Disease incidence of CVd-V was about $66.66 \%$, whereas Cao et al. [18] reported very high incidence because different citrus cultivars were tested in this survey rather than testing maximum samples of 
Kinnow Mandarins, which are heavily infested. The reason for this high viroid disease incidence in Punjab is that the most of the commercial mandarin and sweet orange cultivars are grafted on rough lemon rootstock, which is highly susceptible to viroid diseases. So, it is hereby recommended to use some new disease-free rootstocks.

The Neighbor-Joining tree depicted that the CVd-V isolates detected from Pakistan were closely related to the isolates reported from Iran (GQ466068, KY654684), Spain (EF617306), Pakistan (JQ348930), and the USA (MF477859, MF477876). The central clade with a small branch length consisting of 11 sequences shows these closely related isolates. While, the isolates reported from China, Japan, Tunisia, and North and South Africa are comparatively farther. The closeness of the sequences is also reflected from their sequence distances and percent identity values.

Biological indexing on Etrog citron showed the characteristic symptoms of moderate to severe form and confirmed by RT-PCR results with amplification of 294bp. Synergistic effect of CVd-V with other viroids for mixed infection on indicator plant (Etrog citron) improved leaf symptoms and dwarfing [21]. Synergistic effect of CVd-V with CBLVd and CVd-III on Etrog citron showed severe epinasty and stunting with multiple lesions in the mid vein of a plant. Because of mixed infection of viroids in the main citrus cultivars of Pakistan, the impact of $\mathrm{CVd}-\mathrm{V}$ could not be assessed under normal conditions. Although numbers of the genus Apscaviroid do not prompt definite infections, rather they affect gradually in the form of stunting growth and fruit yield decline. Predictable indexing will provide more evidences of the spreading of $\mathrm{CVd}-\mathrm{V}$ in the world. CVd-V has a wide host range in citrus cultivars as studied by Serra et al. [10]. During this study, it was identified from new citrus cultivars which were not previously investigated from Pakistan. Now, this viroid is distributed worldwide in citrus cultivars. Recently it was reported from Turkey, Nepal, and Pakistan [18, 24] and California [25]. The movement of CVd-V in various geographic regions is presumably the result of the proliferation of contaminated bud wood and the universal trade of plant materials. The natural effect of these movements on CVd-V needs further infectivity assay. In Pakistan, unfortunately most of the citrus nurseries were not registered by the Government and were being handled by non-technical persons. This results in the production of infected plants. Infected bud wood and infected tools are major sources of the spread of viroids. Serious quarantine measures and rules should be imposed to prevent the spread of CVd-V and all other viroids. The nursery should be propagated by technical labor. Hygienic tools should be used in the field during cultural practices. The nursery should be propagated by technical labor. Hygienic tools should be used in the field during cultural practices.

\section{Conclusion}

The infection of CVd-V is increasing in Pakistan and infecting new citrus hosts with small variation in the genome which led to the designing of new primers for its detection. Nurseries and contaminated tools are the main cause of spread of $\mathrm{CVd}-\mathrm{V}$. It is imperative to exploring sources of resistance against $\mathrm{CVd}-\mathrm{V}$ and serious quarantine measures and rules should be imposed to prevent the spread of $\mathrm{CVd}-\mathrm{V}$ and all other viroids. 


\section{Declarations}

Acknowledgements

We are especially grateful to the Chairperson Professor Dr. Rashida Atiq, Department of Plant Pathology, Faculty of Agricultural Sciences \&Technology, Bahauddin Zakariya University Multan for providing support and facilities to perform the Research.

\section{Author Contributions}

Methodology: A.A, U. Umar and A.R; software: U. Umar, M.T.S, M.N.T and S. Atta; validation: U. Umar, S.A, A.R, F.Ö and R.P; formal analysis: A.A and U. Umar; investigation: U. Umar, A.R and R.P; data curation: U. Umar, M.T.S and M.N.T; writing-original draft preparation: A.A; writing-review and editing: U. Umar, M.N.T, S. Atta, S.A and F.Ö; visualization: U. Umar, A.R, R.P and M.N.T; supervision: U. Umar and A.R. All authors have read and agreed to the published version of the manuscript.

\section{Data availability}

All data needed to conduct this study is provided within the manuscript and RNA-Seq reads have been submitted to the NCBI database under accession number given in manuscript.

\section{Conflict of Interest}

The authors confirm that this article content has no conflict of interest.

\section{Ethical Approval}

The authors declare that they have no conflict of interest. All authors read the study and showed their willingness to publish this study. This manuscript does not contain any research activity involving the animals or human participants performed by any of the authors.

\section{Consent to Participate and Publish}

The author read the manuscript and showed his willingness to publish this study.

\section{References}

1. Flores R, Minoia S, Carbonell A, Gisel A, Delgado S, López-Carrasco A, Navarro B, Di Serio F (2015). Viroids, the simplest RNA replicons: How they manipulate their hosts for being propagated and how their hosts react for containing the infection. Virus Res 209:136-145

2. Ebrahimi-Moghadam L, Zakiaghl M, Jafarpour B, Mehrvar M (2017). Construction of infectious clones and demonstration of pathogenicity of citrus viroids. Iran J Plant Pathol 53(4):399-415

3. Hadidi A (2019). Next-generation sequencing and CRISPR/Cas13 editing in viroid research and molecular diagnostics. Viruses 11(2):120 
4. Chambers GA, Geering AD, Holford P, Vidalakis G, Donovan NJ (2022). Development of a one-step RTqPCR detection assay for the newly described citrus viroid VII. J Virol Methods 299:114330

5. Gobatto D, Chaves AL, Harakava R, Marque JM, Daròs JA, Eiras M (2014). Chrysanthemum stunt viroid in Brazil: Survey, identification, biological and molecular characterization and detection methods. Plant Pathol 96(1):111-119

6. Matsushita Y, Yanagisawa H, Sano T (2018). Vertical and horizontal transmission of Pospiviroids. Viruses 10(12):706.

7. Katsarou K, Chiumenti M, Kalantidis K, Mathioudakis MM (2020). First Report of Citrus Viroids Infecting Persian (Tahiti) Lime in Greece. Plant Dis 104(3):998

8. Hamdi I, Elleuch A, Bessaies N, Fakhfakh H (2011). Insights on genetic diversity and phylogenetic analysis of Hop stunt viroid (HSVd) population from symptomatic citrus tree in Tunisia. Afr $\mathrm{J}$ Microbiol Res 5(21):3422-3431

9. Ito T, leki H, Ozaki K, Ito T (2001). Characterization of a new citrus viroid species tentatively termed Citrus viroid OS. Arch Virol 146(5):975-982

10. Serra P, Barbosa CJ, Daròs JA, Flores R, Duran-Vila N (2008). Citrus viroid V: molecular characterization and synergistic interactions with other members of the genus Apscaviroid. Virology 370(1):102-112

11. Elleuch A, Hamdi I, Bessaies N, Fakhfakh H (2013). Single-strand conformation polymorphism for molecular variability studies of six viroid species. Biosci Biotechnol Biochem 77(1):182-188

12. Keese P, Symons RH (1985). Domains in viroids: evidence of intermolecular RNA rearrangements and their contribution to viroid evolution. Proceedings of the National Academy of Sciences PNAS 82(14):4582-4586.

13. Giguere T, Perreault JP (2017). Classification of the Pospiviroidae based on their structural hallmarks. Pone 12(8):e0182536

14. Najar A, Hamdi I, Ben Mahmoud K (2018). Citrus viroids: characterization, prevalence, distribution and struggle methods. J New Sci 50:3129-3137.

15. Chambers GA, Bogema DR, Englezou A, Donovan NJ (2020). First Report of Citrus Viroid V and Citrus Viroid VI in Australia Infecting Citrus. Plant Dis104 (7):2037

16. Vernière C, Perrier X, Dubois C, Dubois A, Botella L, Chabrier C, Bové JM, Vila ND (2004). Citrus viroids: symptom expression and effect on vegetative growth and yield of clementine trees grafted on trifoliate orange. Plant Dis 88(11):1189-1197

17. Tessitori, M (2017): Apscaviroids infecting citrus trees. In: Ahmed H, Ricardo F, John WR, Peter P eds. Viroids and Satellites. Academic Press, USA, pp. 243-249

18. Cao M, Atta S, Su H, Wang X, Wu Q, Li Z, Zhou C (2013). Molecular characterization and phylogenetic analysis of Citrus viroid $V$ isolates from Pakistan. Eur J Plant Pathol 135(1):11-21

19. Barbosa CJ, Pina JA, Pérez-Panadés J, Bernad L, Serra P, Navarro L, Duran-Vila N (2005). Mechanical transmission of citrus viroids. Plant Dis 89(7):749-54 
20. Hamdi I, Elleuch A, Bessaies N, Grubb CD, Fakhfakh H (2015). First report of Citrus viroid Vin North Africa. J Gen Plant Pathol 81(1):87-91

21. Serra P, Pina JA, Durán-Vila N (2010). Identification and characterization of a variant of Citrus viroid $V(\mathrm{CVd}-\mathrm{V})$ in Seminole tangelo. In Seventeenth Conference of the International Organization of Citrus Virologists (IOCV) pp. 150-157

22. Hashemian SB, Taheri H, Alian YM, Bové JM, Durán-Vila N (2013). Complex mixtures of viroids identified in the two main citrus growing areas of Iran. Plant Pathol 1:647-654

23. Hashemian SB, Serra P, Barbosa CJ, Juárez J, Aleza P, Corvera JM, Lluch A, Pina JA, Durán-Vila N (2009). Effect of a field-source mixture of citrus viroids on the performance of 'Nules' Clementine and 'Navelina'sweet orange trees grafted on Carrizo Citrange. Plant Dis 93(7):699-707.

24. Önelge N, Yurtmen M (2012). First report of Citrus viroid Vin Turkey. Plant Pathol 94(4): 1-2

25. Dang T, Tan SH, Bodaghi S, Greer G, Lavagi I, Osman F, Ramirez B, Kress J, Goodson T, Weber K, Zhang YP (2018). First Report of Citrus viroid V Naturally Infecting Grapefruit and Calamondin Trees in California. Plant Dis 102(10):2050-.2050

26. Naqvi SA, Atta S, Liu H, Rehman AU, Khan AA (2017). Serological and molecular based detection of graft-transmissible pathogens associated with citrus from non-core areas of Pakistan. Paki J Agric Sci 54(4):793-799

27. Yaqub MS, Khan IA, Usman M, Rana IA (2017). Molecular detection of Candidatus Liberibacter asiaticus, the causal organism of huanglongbing (Citrus greening) in Faisalabad, Pakistan for huanglongbing management. Pak J Agric Sci 54(1): 21-26

28. Zhou C, da Graça JV, Freitas-Astua J, Vidalakis G, Durán-Vila N, Lavagi I (2020). Citrus viruses and viroids. In: Manuel T., Marco C., Fred G. (eds). The Genus Citrus. Wood head Publishing UK, PP 391410

29. Roistacher CN (1991). Graft-transmissible diseases of citrus: Handbook for detection and diagnosis. FAO Public Division, pp.286

30. Steyn C, Cook G, Burger JT, Maree HJ (2016). Construction and application of infectious citrus viroids for biological indexing. J Cit Pathol 3(1):1-7

31. Fiore N, Zamorano A, Pino AM, González F, Rosales IM, Sánchez-Navarro JA, Pallás V (2016). Survey of stone fruit viruses and viroids in Chile. Plant Pathol 1:631-635

32. Altschul SF, Madden TL, Schäffer AA, Zhang J, Zhang Z, Miller W, Lipman DJ (1997). Gapped BLAST and PSI-BLAST: A new generation of protein database search programs. Nucleic Acids Res 25(17):3389-3402

33. Tamura K, Peterson D, Peterson N, Stecher G, Nei M, Kumar S (2011). MEGA5: Molecular evolutionary genetics analysis using maximum likelihood, evolutionary distance, and maximum parsimony methods. Mol Bio Evol 28(10):2731-2739

34. Tamura MN, Fuse S, Azuma H, Hasebe M (2004). Biosystematic studies on the family Tofieldiaceae I. Phylogeny and circumscription of the family inferred from DNA sequences of matK and rbcL. Plant Biol 6(05):562-567 
35. Memon NA, Kasbit D (2017). Citrus fruit (Kino): Punjab produced $98 \%$ of production. Exclusive on Kino 29-31.

36. Cao MJ, Atta S, Liu YQ, Wang XF, Zhou CY, Mustafa A, Iftikhar Y (2009). First Report of Citrus bent leaf viroid and Citrus dwarfing viroid from Citrus in Punjab, Pakistan. Plant Dis 93(8):840-840.

37. Vernière $C$, Perrier X, Dubois C, Dubois A, Botella L, Chabrier C, Bové JM, Vila ND (2006). Interactions between citrus viroids affect symptom expression and field performance of clementine trees grafted on trifoliate orange. Phytopathol 96(4):356-368

38. Ito T, Ohta S (2010). First report of Citrus viroid Vin Japan. J Gen Plant Pathol 76(5):348-350

\section{Figures}

\section{Figure 1}

Gel electrophoresis analysis shows amplified products of 293bp from symptomatic leaves (Lane 1-9) collected from Khanewal, Sargodha, Lay Layyah, and Sahiwal. Lane M represents 100bp Ladder (Invitrogen) and lane N: negative control.

\section{Figure 2}

Symptoms shown by grafted Etrog citron plants infected with CVd-V control plant (A) severe epinasty 3-5 months after grafting (B) severe bark cracking 3-8 weeks after grafting (C) severe stunting as compared to healthy control (D). 


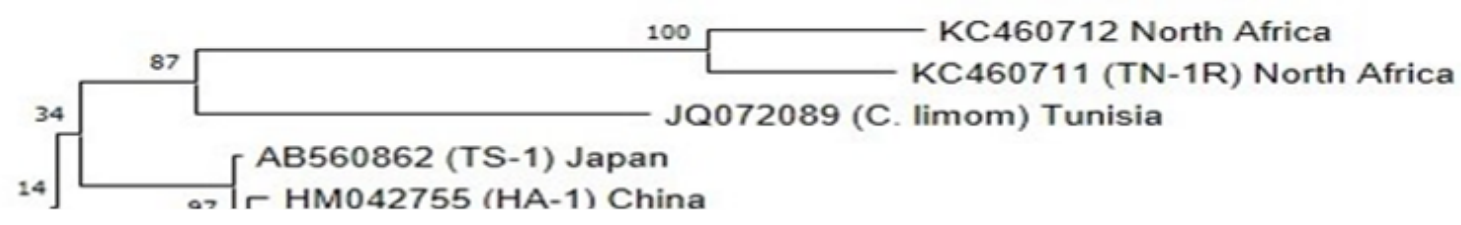

\section{Figure 3}

Phylogenetic analysis of Citrus Viroid V (CVd-V) sequences. Shown is a Neighbor-Joining phylogenetic dendrogram based upon alignment of nucleotide sequences of the $\mathrm{CVd}-\mathrm{V}$ isolates produced as a part of the study presented here with selected CVd-V. 


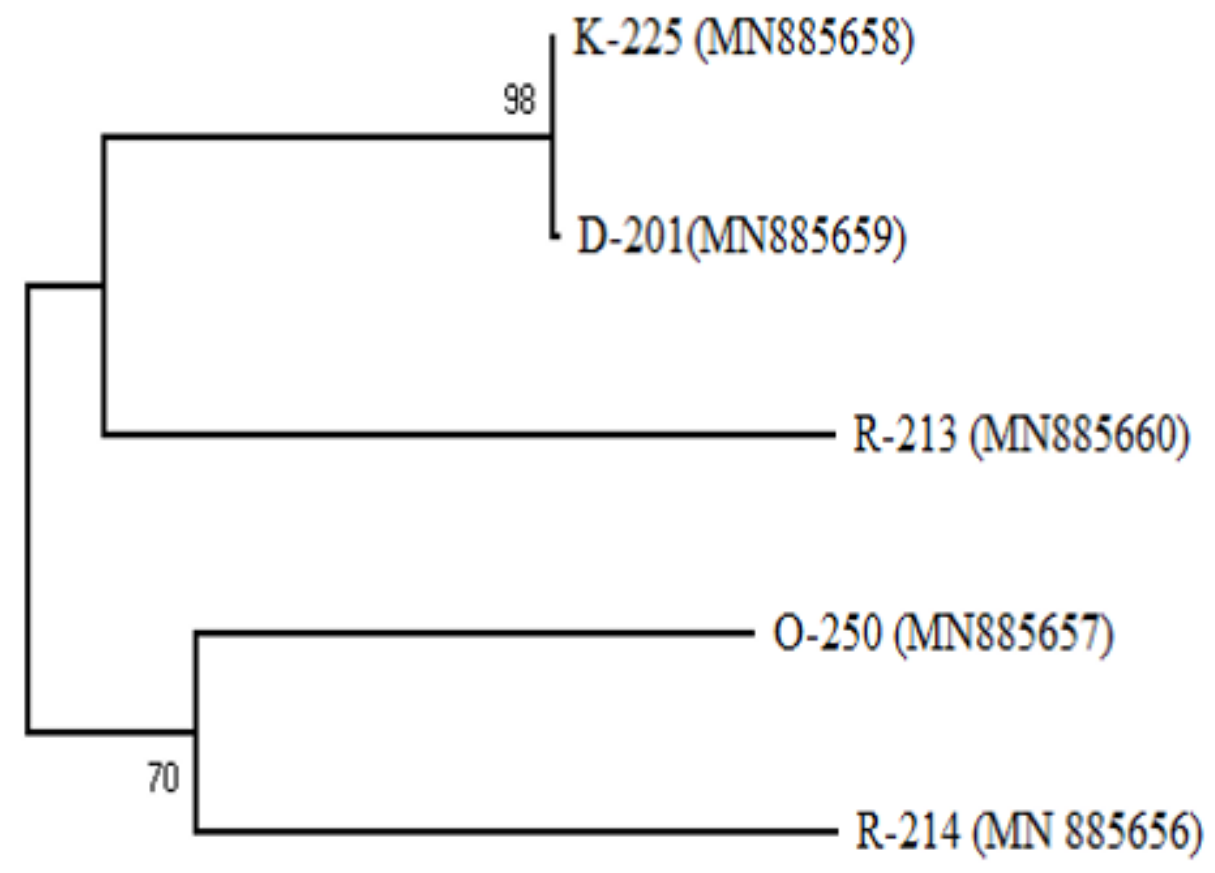

Figure 4

Phylogenetic tree of Citrus Viroid V (CVd-V) shows the interaction

\section{Supplementary Files}

This is a list of supplementary files associated with this preprint. Click to download.

- SupplementaryTable.pdf

- SupplymentryFig.pdf 